\title{
The acquisition of Croatian prepositional phrases by mono- and bilingual children
}

\author{
Gordana Hržica \\ gordana.hrzica@erf.unizg.hr \\ Sciences, University of Zagreb \\ Marina Čamber \\ marina.camber@ph-noe.ac.at \\ University College of Teacher Education in Lower Austria \\ Ana Kaštelančić Igrc \\ ana.kastelancic@gmail.com \\ "Slava Raškaj" Educational Centre Split
}

Department of Speech Therapy, Faculty of Education and Rehabilitation

Children acquire prepositional phrases later than content words during language acquisition. This paper aims to describe the acquisition of prepositional phrases in Croatian, focusing on the order of their acquisition and the influence of their frequency in child-directed speech. To gain insight into the early acquisition of prepositional phrases, the longitudinal spontaneous child speech (CS) and child-directed speech (CDS) of three monolingual children were analysed, as well as a smaller sample of CS and CDS from four bilingual children.

The results suggest that the acquisition of prepositional phrases is similar for monolingual and bilingual speakers, and that it depends on how often the children hear the prepositional phrases. Our findings generally support the idea that language development in bilingual children is similar to that of monolingual children, but that an analysis of a larger sample of bilingual children is needed.

Keywords: child language, child-directed speech, frequency, monolingual development, bilingual development, prepositions 


\section{INTRODUCTION}

A prepositional phrase consists of an initial preposition, object and optional modifiers of the object. Prepositional phrases are therefore more complex than lexical (content) words, and they require more time to be fully acquired. In Russian, for example, Leikin (1998) showed that the prepositional system is not acquired until the age of 7 years. Moreover, the order in which prepositional phrases are acquired seems to differ only minimally across various languages. In English and some other languages, phrases containing the prepositions in, on, beside, under, back and front are acquired first (Johnston \& Slobin, 1979). It is conceivable that because Croatian is a highly inflected and morphologically rich language, children may take longer to acquire prepositional phrases than children learning, for example, German (Kovačević, Palmović, \& Hržica, 2009). This question has remained unanswered because the acquisition of prepositional phrases in Croatian has not been thoroughly explored.

How often children encounter lexical elements (i.e. frequency in language) influences both their acquisition and processing at different levels (Ellis, 2002). Since the 1970s, research has emphasised the role of frequency: Brown (1973) pointed out that words frequently used in child-directed speech (CDS) tend to match children's cognitive predilections. Research supporting the importance of frequency in language acquisition by children has focused largely on the language input, primarily nouns and verbs, that children receive (for an overview, see Ambridge \& Lieven, 2011). Frequency-based corpus studies often calculate frequencies from CDS, such as Savić and Anđelković (2011), who found input frequency to be crucial for the acquisition of prepositional phrases in Serbian. There are, however, studies focusing on more general measures of frequency, including written adult language. One example is Savić and Anđelković (2004), who compared prepositional phrases in child speech (CS) to adult written language sources.

In the present study, we explored the effects of preposition frequency in CDS on the acquisition of Croatian prepositional phrases by mono- and bilingual children. Among scholars, there is a broad consensus that morpho-syntactic acquisition proceeds similarly in the two types of children (e.g. De Houwer, 2005; Brian MacWhinney, 2005; Reich, 2008).

\subsection{Prepositions and prepositional phrases in child speech}

The order in which children begin to use various elements during their language acquisition has been explored since the early years of child language 
research. Some of these studies focus only on prepositions, without considering the prepositional phrase.

Scholars such as Brown (1973), Slobin (1973) and Johnston and Slobin (1979) have advocated for cross-linguistic research in order to determine possible universalities in the acquisition of prepositions and prepositional phrases. Early studies by Johnston and Slobin (1979) analysed the order of appearance of seven locative prepositional phrases in four languages (English, Italian, Serbo-Croatian and Turkish). They found that phrases in the four languages shared the following general order of appearance: (1) in, on, under, beside; (2) between, back, front, with the latter two prepositional phrases having featured objects; and (3) back and front, without featured objects. Featured objects are those with an intuitively obvious "back" and "front", such as houses or people, as opposed to "glasses" or "trees", where "back" and "front" depend on the point of view (ibid., p. 530). This sequence was confirmed for English by Durkin (1981), for the Romance languages by Clark (1986) and partially confirmed for Hebrew by Dromi (1979) as well as other languages (for an overview, see Rivière, Lécuyer, \& Hickmann, 2009).

Tomasello (1987) observed the early use of English prepositional phrases of one child during her second year of life. In contrast to previous studies, Tomasello (ibid.) did not limit prepositions to spatial ones but considered the broader category. He established an order of appearance as up-down, then on-off, then in-out and then over-under. However, these prepositions did not appear in prepositional phrases, but rather as holophrastic elements.

Research that has investigated the acquisition of prepositions and prepositional phrases in different languages has confirmed that other types of prepositions (namely, with, by, to, for, at and of) appear after spatial prepositions (e.g. in, on, under, beside, between, back, front) (Tomasello, 1987). The literature on child language development has perhaps devoted most of its attention to spatial prepositions and prepositional phrases (e.g. Armon-Lotem, 2014; Johnston \& Slobin, 1979; Korecky-Kröll \& Buchegger, 2018; Leikin, 1998). Such research has determined that early during their language development, children gradually develop an understanding of spatial relations (cf. Clark, 2004). Clark (1973) found that 1- and 2-yearolds were unaware of the spatial relations of the words in, on and under until they had acquired certain concepts for understanding objects and their locations. Thus, it seems that children use non-linguistic strategies before they follow locative instructions; in other words, they rely initially on the spatial words they know, then eventually establish word meaning. These 
non-linguistic strategies appear to have an important impact on language acquisition by children (cf. Clark, 2004, 1973).

\subsection{Prepositions and prepositional phrases in bilingual acquisition}

There is a broad consensus among scholars that bilingual children acquire language similarly to their monolingual peers, especially in early childhood (e.g. De Houwer, 2005; Brian MacWhinney, 2005; Reich, 2008). Moreover, numerous studies examining German as a second language highlight similar developmental stages of grammar acquisition among bilinguals acquiring it (e.g. Grießhaber, 2012; Jeuk, 2003; Meisel, 2001; Pienemann, 1998). Thus, the literature suggests that bilinguals differ from monolinguals not in their language acquisition processes, but in their linguistic competence. Variability in input language (e.g. Gathercole \& Thomas, 2005; Jeuk, 2003; Pearson, 2008) leads to variability in language dominance (e.g. Place \& Hoff, 2011), leading one language to become dominant. This lack of balance leads to interference (Weinreich 1953) and transfer (see Major 2008), which can facilitate and/or inhibit bilingual learning (e.g. Paradis \& Genesee 1996).

These general findings can also be applied to prepositions and prepositional phrases. The principles guiding acquisition of prepositions and prepositional phrases appear to be similar for mono- and bilingual children. Spatial prepositions are acquired first, followed by temporal prepositions, and then by other prepositions (for an overview, see Klinge, 1994). Simultaneous acquisition of two languages may lead to specific language phenomena such as transfer. The simultaneous acquisition of prepositions may be influenced by the nature of the languages themselves: children may begin to use some prepositions earlier in one language than in the other due to their greater simplicity or transparency (cf. Grosjean, 2010; Yip \& Matthews, 2007). Nevertheless, the acquisition of prepositions and prepositional phrases and the general principles guiding it largely overlap between bi- and monolinguals.

\subsection{Prepositions and prepositional phrases in the Croatian language}

Prepositions are an extensively used word class in Croatian. As Matovac (2013) summarises, the third most frequent word in Croatian is the preposition $u$ 'in' and an additional 13 prepositions are included in the list of the 100 most frequent Croatian words (Moguš, Bratanić, \& Tadić, 1999).

In the prepositional phrase prepositions are usually followed by a noun in one of the five cases: accusative (Acc), locative (Loc), instrumental (In- 
str), genitive (Gen) or dative (Dat). Some prepositions may be followed by a noun in different cases. For example, some prepositions express a static locative meaning when followed by a noun in locative (e.g. Ja sam $\boldsymbol{u}$ kući. 'I'm in the house.), or a directional meaning when followed by a noun in accusative case (Ja idem $\boldsymbol{u}$ kuću. 'I go (in)to the house.') Children appear to struggle with these types of prepositional phrases in both Croatian and German. Research by Poljak, Hržica and Arapović (2015) and by Hržica, Brdarić, Tadić, Goleš, and Roch (2015) demonstrated children's insecurities in using such phrases: they would sometimes fail to differentiate locative and directional meaning, but rather they would use the preposition and the noun in locative case in order to express both locative and directional meaning (e.g. Idemo $u$ "parku. Let's go to the park.'). This behaviour has also been observed in other languages. Among L1 Turkish children acquiring German, Grießhaber (2007) observed that children have problems using dative and accusative, which is analogous to the place/goal distinction in Croatian, and that such problems can persist until the end of primary school.

While Croatian prepositions as semantic elements have been extensively analysed, their appearance in early child language has been neglected. To the best of our knowledge, this subject has been examined only by Kaštelančić (2014), who described early preposition use from the perspective of preposition heterogeneity. A handful of studies have examined errors made by children when using prepositions and prepositional phrases (Poljak et al., 2015; Županović Filipin, 2015) or have mentioned them when talking about other language features (e.g. Kovačević \& Anđel, 1999; Kovačević et. al., 2009).

\section{AIM AND RESEARCH QUESTIONS}

Since we are unaware of systematic research on the acquisition of prepositional phrases in Croatian, the aim of the present study was to describe the order of appearance of prepositional phrases in CS, track changes in their usage during development and assess how the frequency of children's exposure to those phrases affects their appearance during language acquisition.

We posed three research questions:

1. What is the order of acquisition of prepositional phrases?

2. Are there developmental changes in the number and diversity of prepositional phrases?

3. What is the role of frequency in CDS in the acquisition of prepositional phrases? 
In all three cases, we expected to obtain similar results between monoand bilingual children.

\section{METHOD}

\subsection{Participants and materials}

The participants in this study were three monolingual (L1) and four simultaneously bilingual (2L1) Croatian-speaking children. The children in the monolingual group (Table 1) grew up in the urban area of Zagreb, Croatia, whereas the children in the bilingual group (Table 2) were born and raised in Vienna, Austria and were simultaneously exposed to Croatian and German through their families and their surroundings. Nevertheless, the relative uses of the two languages varied across the bilingual children (see Camber, 2020).

All children were audio- and video-recorded during spontaneous speech interactions with their mothers or other caretakers at home according to standard ethical procedures. For the monolingual participants, longitudinal data were available from the age of $1 ; 5$ years to $3 ; 0$ years (see Table 1 ), whereas exemplary data for the bilingual group were available from two time points during the children's third year of life (see Table 2). Monolingual spontaneous speech data were obtained from the Corpus of Croatian Child Language (Kovačević, 2002), while bilingual data were collected as a part of the present study. Transcripts of mono- and bilingual children also included CDS. Although recorded interactions occurred most often with mothers, other individuals (e.g. other family members) were occasionally present during the recordings, and the input of all recorded individuals was taken into account as CDS.

Table 1. Spontaneous speech data for monolingual children

\begin{tabular}{llll}
\hline \multirow{2}{*}{ Variable } & \multicolumn{3}{c}{ Child } \\
\cline { 2 - 4 } & Antonija & Marina & Vjeran \\
\hline Age & $1 ; 3-2 ; 8$ & $1 ; 5-2 ; 11$ & $0 ; 10-3 ; 2$ \\
Hours of recording & 10 & 21 & 35 \\
Number of lemmas in CS & 1,322 & 1,745 & 3,632 \\
Number of lemmas in CDS & 2,865 & 2,538 & 10,738 \\
Number of tokens in CS & 15,019 & 25,302 & 49,481 \\
Number of tokens in CDS & 35,899 & 37,984 & 133,533 \\
\hline
\end{tabular}


Data for the bilingual children were gathered as part of the doctoral work of one of the authors (see Čamber, 2020) and represent an exploratory sample of one hour of recorded spontaneous speech for each of four children aged between 3;0 and 3;4 years (see Table 2).

Table 2. Spontaneous speech data for bilingual children

\begin{tabular}{lllll}
\hline \multirow{2}{*}{ Variable } & \multicolumn{3}{c}{ Child } \\
\cline { 2 - 5 } & Ana & Lara & Filip & Marko \\
\hline Age & $3 ; 0-3 ; 3$ & $3 ; 1-3 ; 4$ & $3 ; 1-3 ; 4$ & $3 ; 0-3 ; 3$ \\
Hours of recording & 1 & 1 & 1 & 1 \\
Number of lemmas in CS & 492 & 423 & 426 & 318 \\
Number of lemmas in CDS & 664 & 734 & 613 & 718 \\
Number of tokens in CS & 1,317 & 1,019 & 1,373 & 723 \\
Number of tokens in CDS & 2,042 & 2,476 & 2,848 & 3,516 \\
\hline
\end{tabular}

\subsection{Procedure}

Monolingual children were recorded in their homes or immediate surroundings two or three times a month, from the onset of speech until approximately three years of age (Antonija: 2;08, Marina: 3;0, Vjeran 3;03). More details can be found in Hržica $(2011,2012)$ and in a "read_me" file within the Corpus of Croatian Child Language (https://childes.talkbank. org/access/Slavic/Croatian/Kovacevic.html). Bilingual children were recorded at two time points three months apart, when children were 3;0-3;4 years old. For each recording, 30 minutes containing the richest speech interaction were selected for transcription. The speech samples were transcribed and coded within the CLAN program of the CHILDES system (MacWhinney, 2000).

Because parental input is viewed as one of the key factors in children's language acquisition (e.g. Cartmill et al. 2013; Cristofaro \& Tamis-LeMonda 2012; De Houwer 2007; Korecky-Kröll et al. 2016), parental CDS was also analysed. The frequencies of all word tokens and preposition tokens were extracted using the freq command in CLAN and imported into Microsoft Excel. In addition, the percentage of prepositional phrases in CS and CDS was calculated for each child. 


\section{RESULTS}

\subsection{Order of acquisition of Croatian prepositional phrases}

The first appearance of prepositional phrases in the monolingual corpus was recorded between 1;7 and 1;9 years (Marina: 1;9. Antonija: 1;7 and Vjeran: $1 ; 8)$ with the prepositions $u$ 'in' and $n a$ 'on'. Prepositions accounted for approximately $6 \%$ of all tokens during each month of recording $(\mathrm{min}=$ $0, \max =21$, mean $=6.18, \mathrm{SD}=5.302$ ). Among all utterances, a maximum of $10 \%$ per month included a preposition $(\min =0, \max =10$, mean $=3.85$, $\mathrm{SD}=3.161$ ). The number of prepositions, the percentage of prepositions in tokens and the percentage of prepositions per utterance increased with chronological age, and all three correlations were strong [number: $\mathrm{r}=.795$, $\mathrm{p}<.001$; percentage (tokens): $\mathrm{r}=.816, \mathrm{p}<.001$; percentage (utterances): $\mathrm{r}$ $=.820, \mathrm{p}<.001]$.

Example (1). First use of a prepositional phrase in Marina's CS Marina 1;9 years

*CHI: u pijesku in-LOC 'in the sand' sand-LOC.sg

Children started producing prepositional phrases at approximately the same time (Marina - 1;9, Antonija 1;7, Vjeran - 1;8), and Table 3 indicates in which months they used each phrase again, with data analysed up to 14 months after initial use. For all three children, the first preposition was $u$ 'in', used to express both location and direction. The second preposition was $n a$, again used to express both location ('at, on') and direction ('to, on'). These two early prepositional phrases were soon followed by $s(a): I n s t r$ 'with', $z a: A c c$ 'for' and od:Gen 'from, of'. Next to appear were spatial prepositional phrases po:Loc 'alongside' and po:Acc 'for', as well as iz:Gen 'out of', kod:Gen 'at, by' and s:Gen 'from. The table shows that the three children gradually used more prepositional phrases with time, that some phrases were used routinely but others less often, and that some phrases were used only by some children while others were used by all three. 
Table 3. Appearance of Croatian prepositional phrases in L1 child language*

\begin{tabular}{|c|c|c|c|c|c|c|c|c|c|c|c|c|c|c|c|c|c|}
\hline Case & Meaning & Child & 1 & 2 & 3 & 4 & 5 & 6 & 7 & 8 & 9 & 10 & 11 & 12 & 13 & 14 & 15 \\
\hline \multirow[t]{3}{*}{$\mathrm{u}: \mathrm{Acc}$} & \multirow{3}{*}{ 'in, to' } & Marina & + & + & + & + & + & + & + & + & + & + & + & + & + & + & + \\
\hline & & Antonija & + & + & + & + & + & + & + & + & + & + & + & + & + & + & \\
\hline & & Vjeran & + & & + & + & + & + & + & + & + & + & + & + & + & + & + \\
\hline \multirow[t]{3}{*}{ u:Loc } & \multirow{3}{*}{ 'in' } & Marina & + & + & + & + & + & + & + & + & + & + & + & + & + & + & + \\
\hline & & Antonija & + & + & + & + & + & + & + & + & + & + & + & + & + & & \\
\hline & & Vjeran & + & + & + & + & + & + & + & + & + & + & + & + & + & + & + \\
\hline \multirow[t]{3}{*}{ na:Acc } & \multirow{3}{*}{ 'to, on' } & Marina & & & & + & + & + & + & + & + & + & + & + & + & + & + \\
\hline & & Antonija & & & & + & + & + & + & + & + & + & + & + & + & + & \\
\hline & & Vjeran & & & + & + & + & + & + & + & + & + & + & + & + & + & + \\
\hline \multirow[t]{3}{*}{ na:Loc } & \multirow{3}{*}{ 'at, on(to)' } & Marina & & + & + & + & + & + & + & + & + & + & + & + & + & + & + \\
\hline & & Antonija & & & & + & + & + & + & + & + & + & + & + & + & + & \\
\hline & & Vjeran & & & + & + & + & + & + & + & + & + & + & + & + & + & + \\
\hline \multirow[t]{3}{*}{ s(a):Instr } & \multirow{3}{*}{ 'with' } & Marina & & & + & + & & + & + & + & + & + & + & + & + & + & + \\
\hline & & Antonija & & & & & & & + & + & + & + & + & + & + & + & + \\
\hline & & Vjeran & & + & + & + & + & + & + & + & + & + & + & + & + & + & + \\
\hline \multirow[t]{3}{*}{ za:Acc } & \multirow{3}{*}{ 'for' } & Marina & & & & & + & + & + & + & + & + & + & + & + & + & + \\
\hline & & Antonija & & & & & & & + & + & & + & + & & & + & \\
\hline & & Vjeran & & & & & + & + & + & + & + & + & + & + & + & + & + \\
\hline \multirow[t]{3}{*}{ od:Gen } & \multirow{3}{*}{ 'from, of' } & Marina & & & + & + & + & + & + & + & + & + & + & + & + & + & + \\
\hline & & Antonija & & & & & & & & + & & + & + & + & + & & \\
\hline & & Vjeran & & & & & + & + & + & + & + & + & + & + & + & + & + \\
\hline \multirow[t]{3}{*}{ po:Loc } & \multirow{3}{*}{$\begin{array}{l}\text { 'along- } \\
\text { side' }\end{array}$} & Marina & & & & + & + & & & & + & & & & & + & \\
\hline & & Antonija & & & & + & + & & + & + & + & + & & + & & & \\
\hline & & Vjeran & & & & & & + & & + & + & + & & & & & + \\
\hline \multirow[t]{3}{*}{ iz:Gen } & \multirow{3}{*}{ 'out of' } & Marina & & & & & & + & & & & + & & & & & \\
\hline & & Antonija & & & & & & & + & & + & & & & + & & \\
\hline & & Vjeran & & & & & & & + & & & + & + & & + & + & + \\
\hline \multirow[t]{3}{*}{ po:Acc } & \multirow{3}{*}{ 'for' } & Marina & & & & & & & & & + & & + & & & & \\
\hline & & Antonija & & & & & & & & & & + & & & + & & \\
\hline & & Vjeran & & & & & & & & & & + & + & & & & \\
\hline \multirow[t]{3}{*}{ kod:Gen } & \multirow{3}{*}{ 'at, by' } & Marina & & & & & & & & & & + & + & + & + & + & + \\
\hline & & Antonija & & & & & & & & & & & & + & + & & \\
\hline & & Vjeran & & & & & & & + & + & + & + & + & + & + & + & + \\
\hline s:GEN & & Marina & & & & & & + & & & & + & + & & & & \\
\hline & 'from' & Antonija & & & & & & & & & & & & & + & & \\
\hline & & Vjeran & & & & & & & & & & & + & & & & + \\
\hline
\end{tabular}

* The column ' 1 ' corresponds to the first month that the child was recorded using the indicated prepositional phrase, and then the subsequent 14 months are indicated with the numbers ' 2 ' through ' 15 '. One or more uses of the same prepositional phrase in each subsequent month is indicated with a ' + '.

All prepositional phrases used by the monolingual children were also used by the bilingual children, who were older at both time points analysed 
(age 3;0/3;1 and 3;3/3;4). However, only some phrases were used by all four bilingual children. Due to the rather small exploratory sample, the children produced only 11 prepositional phrases in total (Table 4). The only phrase that appeared among bilinguals but not monolinguals was $u z: A c c$ 'at, by, along. Some prepositional phrases were used by only one bilingual child, and several were used at only one of the two time points, e.g. Marko used pod:Gen 'under' or uz:Acc 'at, by, along. This can be explained by the fact that children used certain prepositional phrases only in certain situations (e.g. during play).

Table 4. The appearance of Croatian prepositional phrases in $2 \mathrm{~L} 1$ child language*

\begin{tabular}{|c|c|c|c|c|}
\hline Case & Meaning & Child & 1 & 2 \\
\hline \multirow[t]{4}{*}{$\mathrm{u}: \mathrm{Acc}$} & \multirow{4}{*}{ 'in, to' } & Ana & & + \\
\hline & & Lara & + & \\
\hline & & Marko & + & + \\
\hline & & Filip & + & + \\
\hline \multirow[t]{4}{*}{$\mathrm{u}:$ Loc } & \multirow{4}{*}{ 'in' } & Ana & + & + \\
\hline & & Lara & + & + \\
\hline & & Marko & + & \\
\hline & & Filip & + & + \\
\hline \multirow[t]{4}{*}{ na:Acc } & \multirow{4}{*}{ 'to, on' } & Ana & & \\
\hline & & Lara & + & \\
\hline & & Marko & + & + \\
\hline & & Filip & + & + \\
\hline \multirow[t]{4}{*}{ na:Loc } & \multirow{4}{*}{ 'at, on(to)' } & Ana & + & + \\
\hline & & Lara & + & \\
\hline & & Marko & & \\
\hline & & Filip & & + \\
\hline \multirow[t]{4}{*}{ s(a):Instr } & \multirow{4}{*}{ 'with' } & Ana & + & + \\
\hline & & Lara & & \\
\hline & & Marko & & + \\
\hline & & Filip & & \\
\hline \multirow[t]{4}{*}{ za:Acc } & \multirow{4}{*}{ 'for' } & Ana & + & + \\
\hline & & Lara & + & \\
\hline & & Marko & & \\
\hline & & Filip & & + \\
\hline
\end{tabular}

\begin{tabular}{|c|c|c|c|c|}
\hline Case & Meaning & Child & 1 & 2 \\
\hline \multirow[t]{4}{*}{ od:Gen } & \multirow{4}{*}{ 'from, of' } & Ana & + & + \\
\hline & & Lara & + & \\
\hline & & Marko & & \\
\hline & & Filip & & \\
\hline \multirow[t]{4}{*}{ kod:Gen } & \multirow{4}{*}{ 'at, by' } & Ana & + & + \\
\hline & & Lara & + & \\
\hline & & Marko & & \\
\hline & & Filip & & \\
\hline \multirow[t]{4}{*}{ bez:Gen } & \multirow{4}{*}{ 'without' } & Ana & + & + \\
\hline & & Lara & & \\
\hline & & Marko & & \\
\hline & & Filip & & \\
\hline \multirow[t]{4}{*}{ ispod:Gen } & \multirow{4}{*}{ 'under' } & Ana & & \\
\hline & & Lara & & \\
\hline & & Marko & + & \\
\hline & & Filip & & \\
\hline \multirow[t]{4}{*}{ uz:Acc } & \multirow{4}{*}{ 'at, by, along' } & Ana & & \\
\hline & & Lara & & \\
\hline & & Marko & + & \\
\hline & & Filip & & \\
\hline
\end{tabular}

* The ' 1 ' corresponds to the early time point when children were aged $3 ; 0 / 3 ; 1$. The ' 2 ' corresponds to the time point when they were age 3;3/3;4. At each time point, CS and CDS were recorded for $1 \mathrm{~h}$. One or more uses of the same prepositional phrase in each subsequent month is indicated with a ' + '. 


\subsection{Developmental changes in the number and diversity of prepositional phrases}

Preposition acquisition by monolingual children was evaluated over the course of early development by analysing the 10 prepositional phrases most frequently observed in spontaneous CS at three time points: when children were 1;7-2;0 years old, 2;1-2;6 years old and 2;7-3;0 years old (see Figure 1).

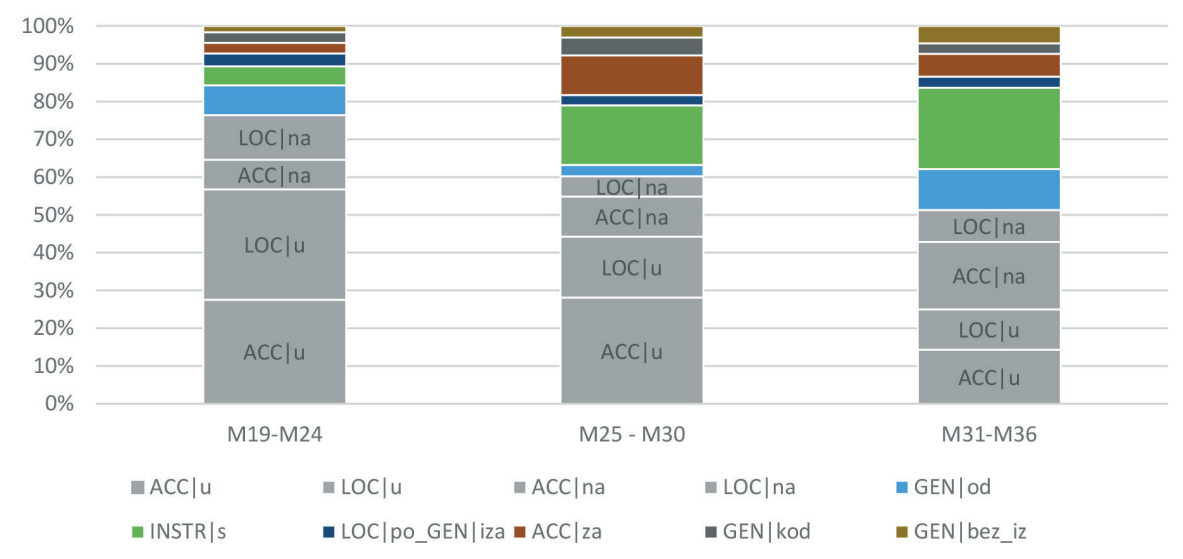

Figure 1. The 10 Croatian prepositional phrases most frequently used by L1 children at three stages of early language acquisition.

The most frequent prepositional phrases at the age of 1;7-2;0 years were $u: L o c$ 'in' and $u: A c c$ 'in, to', followed by na:Loc 'at, on(to)' and na:Acc 'to, on'. Also relatively frequent was the prepositional phrase od:Gen 'from, of' - (8\%). The earlier acquired prepositional phrases with $u$ 'in' and $n a$ 'on' were used most often, accounting for $76 \%$ of all prepositions. At the later age of 2;1-2;6 years, both of these prepositional phrases remained quite common. Nevertheless, their frequency decreased to 60\%, while that of $s(a)$ :Instr 'with' increased to $16 \%$ and that of $z a: A c c$ 'for' to $10 \%$. At 2;7-3;0 years, $u$ 'in' and $n a$ 'on' remained common, but $s(a): I n s t r$ 'with' gained importance and other prepositional phrases became more frequent, indicating a more diverse use of prepositions among older toddlers. Indeed, the earliest acquired prepositional phrases accounted for only $51 \%$ of all prepositional phrases at this age. Pearson correlation analysis indicated that with age, the percentage of early acquired prepositional phrases decreased $(\mathrm{r}=.379, \mathrm{p}<.05)$, while that of other prepositional phrases grew $(\mathrm{r}=.532, \mathrm{p}<.001 ; \mathrm{r}=.322, \mathrm{p}<.05)$. Across all three stages, 32 different prepositional phrases were found. 
Among bilingual children, the prepositional phrases with $u$ 'in' and $n a$ 'on' were very frequent at both time points examined (Figure 2). At the age of 3;0/3; 1 years, these two prepositional phrases dominated, accounting for $49 \%$ of all prepositional phrases ( $u: L o c-20 \%$, u:Acc - 18\%, na:Loc - 4\%, $n a: A c c-7 \%)$. By comparison, prepositional phrases with $u$ 'in' and $n a$ 'on' (in Loc and Acc) represented 51\% of overall preposition use in the speech of monolingual children aged 2;7-3;0 years. The bilingual group used other prepositional phrases at moderate frequencies: za:Acc 'for' - 16\%, s(a):Instr 'with' $-14 \%$ and kod:Gen 'at, by' $-11 \%$. The pattern of prepositional phrases among bilingual children at 3;3-3;4 years was similar to that at the first time point: $u$ 'in' and $n a$ 'on' accounted for $53 \%$ of all prepositional phrases ( $u: L o c$ in $-29 \%, u: A c c-12 \%$; na:Loc - 7\% and na:Acc - 5\%), followed by kod:Gen 'at, by', s(a):Instr 'with' and za:Acc 'for'. Only 11 prepositional phrases were recorded for bilingual children across both time points.

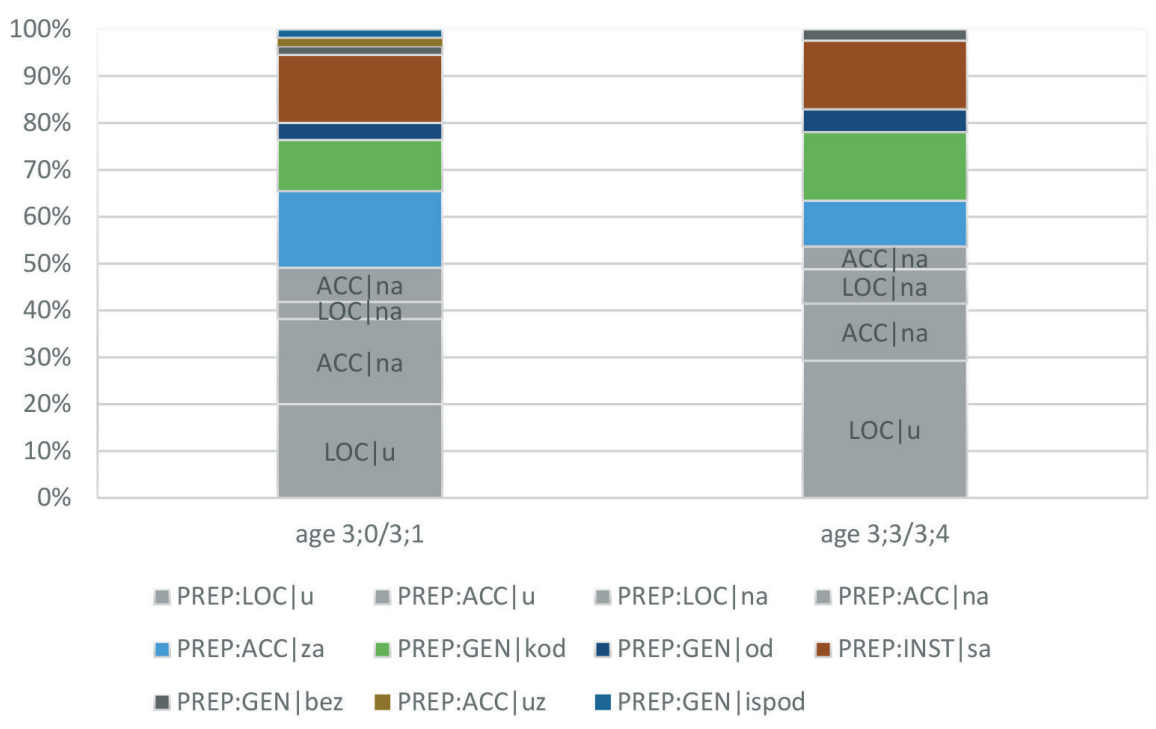

Figure 2. All 11 Croatian prepositional phrases used by $2 \mathrm{~L} 1$ children at two stages of early language acquisition.

\subsection{Frequency of prepositional phrases in child language}

\subsubsection{Monolingual data}

Large differences in the frequencies of different phrases were evident (Table 5), ranging from 396 tokens to only one. The most frequent prepositional phrases were u:Loc/Acc 'in', s(a):Instr 'with', na:Loc/Acc 'at/to/on', za:Acc 
'for' and od:Gen 'from, of', all of which had frequencies greater than 100. Phrases that occurred only once were pod:Instr 'below', izmedu:Gen 'between', iznad:Gen 'over, kraj:Gen 'by', nakon:Gen 'after', pored:Gen 'next to' and $z b o g: G e n$ 'because of.' Vjeran used the most diverse set of prepositional phrases, producing 30 of the 32 prepositional phrases found in the corpus by the age of 3 years. The most frequent types of prepositional phrases in CS had a primarily spatial meaning. Among the seven most frequent prepositional phrases, which appeared in more than 100 tokens, only two were not primarily spatial: $s(a)$ :Instr 'with' and $z a: A c c$ 'for', both of which were used exclusively for people.

The three monolingual children differed in the overall number of prepositional phrases they used, but they used the same phrases with similar frequencies. The four most frequently used prepositional phrases were the same for all three children (Table 5). The least frequent prepositional phrases appeared only once or twice. In light of these similarities, the data from the three children were combined in the comparison between CS and CDS (Table 6).

Table 5. Token frequencies of Croatian prepositional phrases in monolingual CS

\begin{tabular}{|c|c|c|c|c|c|c|}
\hline & $\begin{array}{l}\text { Prepositional } \\
\text { phrases }\end{array}$ & English translation & Marina & Antonija & Vjeran & All \\
\hline 1 & $\mathrm{u}: \mathrm{Acc}$ & in, to (directive) & 102 & 84 & 210 & 396 \\
\hline 2 & s(a):Instr & with & 62 & 47 & 167 & 276 \\
\hline 3 & u:Loc & in (locative) & 80 & 53 & 131 & 264 \\
\hline 4 & na:Acc & to, on & 98 & 33 & 80 & 211 \\
\hline 5 & za:Acc & for & 62 & 16 & 58 & 136 \\
\hline 6 & na:Loc & at, on(to) & 33 & 31 & 54 & 118 \\
\hline 7 & od:Gen & from, of & 25 & 12 & 73 & 110 \\
\hline 8 & kod:Gen & at,by & 21 & 9 & 34 & 64 \\
\hline 9 & iz:Gen & out of & 5 & 5 & 45 & 55 \\
\hline 10 & po:Loc & alongside & 7 & 10 & 17 & 34 \\
\hline 11 & po:Acc & for & 2 & 5 & 18 & 25 \\
\hline 12 & ispod:Gen & under & 1 & 0 & 22 & 23 \\
\hline 13 & iza:Gen & behind & 0 & 0 & 21 & 21 \\
\hline 14 & s:Gen & from & 4 & 1 & 9 & 14 \\
\hline 15 & do:Gen & by & 3 & 0 & 9 & 12 \\
\hline 16 & preko:Gen & over, across & 5 & 0 & 7 & 12 \\
\hline 17 & ispred:Gen & in front of & 0 & 0 & 9 & 9 \\
\hline
\end{tabular}




\begin{tabular}{|l|l|l|l|l|l|l|}
\hline & $\begin{array}{l}\text { Prepositional } \\
\text { phrases }\end{array}$ & English translation & Marina & Antonija & Vjeran & All \\
\hline 18 & kroz:Acc & through & 2 & 1 & 5 & 8 \\
\hline 19 & bez:Gen & without & 1 & 1 & 6 & 8 \\
\hline 20 & o:Loc & about & 1 & 0 & 5 & 6 \\
\hline 21 & oko:Gen & around & 0 & 0 & 4 & 4 \\
\hline 22 & k:Dat & towards & 2 & 0 & 1 & 3 \\
\hline 23 & pokraj:Gen & by & 0 & 1 & 2 & 3 \\
\hline 24 & prije:Gen & before & 0 & 0 & 2 & 2 \\
\hline 25 & prema:Loc & towards, according to & 0 & 0 & 2 & 2 \\
\hline 26 & pod:Acc & under & 0 & 0 & 1 & 1 \\
\hline 27 & između:Gen & between & 0 & 1 & 0 & 1 \\
\hline 28 & iznad:Gen & over & 0 & 0 & 1 & 1 \\
\hline 29 & kraj:Gen & by & 1 & 0 & 0 & 1 \\
\hline 30 & nakon:Gen & after & 0 & 0 & 1 & 1 \\
\hline 31 & pored:Gen & next to & 0 & 0 & 1 & 1 \\
\hline 32 & zbog:Gen & because of & 0 & 0 & 1 & 1 \\
\hline & & All & 517 & 310 & 996 & 1823 \\
\hline & & Tokens (All) & 25,302 & 15,019 & 49,481 & 89,802 \\
\hline & & prepositional phrases & $2 \%$ & $2 \%$ & $2 \%$ & $2 \%$ \\
\hline
\end{tabular}

In the CDS across the three monolingual children, 44 prepositional phrases appeared (Table 6), of which 25 appeared as CDS in the recordings for all three children. The remaining prepositional phrases appeared in recordings for one or two children. While the frequencies of prepositional phrases in CDS varied substantially, the 10 most frequent ones were the same as in the CS of all children, while the least frequent ones were quite similar between adults and children.

Table 6. Token frequencies of Croatian prepositional phrases used in CDS with monolingual children

\begin{tabular}{|l|l|l|l|l|l|l|}
\hline & $\begin{array}{l}\text { Prepositional } \\
\text { phrases }\end{array}$ & English translation & $\begin{array}{l}\text { Marina- } \\
\text { CDS }\end{array}$ & $\begin{array}{l}\text { Antonija- } \\
\text { CDS }\end{array}$ & $\begin{array}{l}\text { Vjeran- } \\
\text { CDS }\end{array}$ & $\begin{array}{l}\text { ALL- } \\
\text { CDS }\end{array}$ \\
\hline 1 & s(a):Instr & with & 214 & 219 & 551 & 984 \\
\hline 2 & u:Loc & in (locative) & 226 & 190 & 542 & 958 \\
\hline 3 & u:Acc & in, to (directive) & 135 & 182 & 613 & 930 \\
\hline 4 & na:Loc & at, on(to) & 158 & 146 & 327 & 631 \\
\hline 5 & na:Acc & to, on & 144 & 156 & 310 & 610 \\
\hline
\end{tabular}




\begin{tabular}{|c|c|c|c|c|c|c|}
\hline & $\begin{array}{l}\text { Prepositional } \\
\text { phrases }\end{array}$ & English translation & $\begin{array}{l}\text { Marina- } \\
\text { CDS }\end{array}$ & $\begin{array}{l}\text { Antonija- } \\
\text { CDS }\end{array}$ & $\begin{array}{l}\text { Vjeran- } \\
\text { CDS }\end{array}$ & $\begin{array}{l}\text { ALL- } \\
\text { CDS }\end{array}$ \\
\hline 6 & za:Acc & for & 91 & 73 & 212 & 376 \\
\hline 7 & od:Gen & from, of & 86 & 51 & 148 & 285 \\
\hline 8 & kod:Gen & at,by & 37 & 37 & 176 & 250 \\
\hline 9 & po:Loc & alongside & 72 & 49 & 108 & 229 \\
\hline 10 & iz:Gen & out of & 40 & 22 & 89 & 151 \\
\hline 11 & do:Gen & by & 7 & 10 & 58 & 75 \\
\hline 12 & s:Gen & from & & 30 & 42 & 72 \\
\hline 13 & po:Acc & for & 5 & 18 & 32 & 55 \\
\hline 14 & ispod:Gen & under & 11 & 3 & 39 & 53 \\
\hline 15 & k:Dat & towards & 9 & 26 & 17 & 52 \\
\hline 16 & kroz:Acc & through & 7 & 6 & 28 & 41 \\
\hline 17 & preko:Gen & over, across & 4 & 7 & 29 & 40 \\
\hline 18 & o:Loc & about & 10 & 3 & 20 & 33 \\
\hline 19 & iza:Gen & behind & 6 & 4 & 21 & 31 \\
\hline 20 & ispred:Gen & in front of & 3 & 1 & 27 & 31 \\
\hline 21 & bez:Gen & without & 4 & 3 & 22 & 29 \\
\hline 22 & prema:Loc & $\begin{array}{l}\text { towards, } \\
\text { according to }\end{array}$ & 8 & & 19 & 27 \\
\hline 23 & kraj:Gen & by & 2 & 4 & 20 & 26 \\
\hline 24 & za:Instr & behind, at & 12 & & 13 & 25 \\
\hline 25 & oko:Gen & around & 4 & 1 & 19 & 24 \\
\hline 26 & prije:Gen & before & 2 & 2 & 13 & 17 \\
\hline 27 & uz:Acc & at, by, along & & & 14 & 14 \\
\hline 28 & pokraj:Gen & by & 2 & 2 & 9 & 13 \\
\hline 29 & nad:Instr & above & & & 11 & 11 \\
\hline 30 & nakon:Gen & after & & 1 & 9 & 10 \\
\hline 31 & poslije:Gen & after & & 2 & 7 & 9 \\
\hline 32 & pod:Acc & under & 3 & 4 & 1 & 8 \\
\hline 33 & pored:Gen & next to & & & 8 & 8 \\
\hline 34 & osim:Gen & except & & 3 & 5 & 8 \\
\hline 35 & pred:Instr & in front of & 1 & & 7 & 8 \\
\hline 36 & zbog:Gen & because of & & & 8 & 8 \\
\hline 37 & između:Gen & between & & 1 & 6 & 7 \\
\hline 38 & iznad:Gen & over & 1 & & 6 & 7 \\
\hline 39 & pod:Instr & below & & 4 & 3 & 7 \\
\hline 40 & blizu:Gen & near & 1 & & 6 & 7 \\
\hline
\end{tabular}




\begin{tabular}{|c|c|c|c|c|c|c|}
\hline & $\begin{array}{l}\text { Prepositional } \\
\text { phrases }\end{array}$ & English translation & $\begin{array}{l}\text { Marina- } \\
\text { CDS }\end{array}$ & $\begin{array}{l}\text { Antonija- } \\
\text { CDS }\end{array}$ & $\begin{array}{l}\text { Vjeran- } \\
\text { CDS }\end{array}$ & $\begin{array}{l}\text { ALL- } \\
\text { CDS }\end{array}$ \\
\hline 41 & umjesto:Gen & instead & & 2 & 4 & 6 \\
\hline 42 & radi:Gen & for & 1 & & 2 & 3 \\
\hline 43 & među:Instr & between & 1 & & 2 & 3 \\
\hline \multirow[t]{4}{*}{44} & pri:Gen & by & & 1 & 1 & 2 \\
\hline & & All & 1307 & 1263 & 3604 & 6149 \\
\hline & & Tokens (All) & 37984 & 35899 & 133533 & 207416 \\
\hline & & $\begin{array}{l}\% \text { of tokens that } \\
\text { were prepositional } \\
\text { phrases }\end{array}$ & $3 \%$ & $4 \%$ & $3 \%$ & $3 \%$ \\
\hline
\end{tabular}

The frequencies of prepositional phrases in CS and CDS showed substantial overlap: the 10 most frequent prepositional phrases in CS were also the 10 most frequent in CDS (Table 7). In addition, all 32 prepositional phrases in CS were also observed in CDS. Differences in ranking were most visible among the three most frequent prepositional phrases: while the most frequent prepositional phrase in CS was $u: L o c$ 'in, to' (directive), it was $s(a)$ :Instr 'with' in CDS, while $u$ :Acc 'in, to' (directive) came third. It is unclear whether these ranking differences between CS and CDS are real, since the differences among them in CDS were quite small. Twelve prepositional phrases observed in CDS were not observed in CS: za:Instr 'behind, at', uz:Acc 'at, by, along, nad:Instr 'above', pod:Instr 'below', pred:Instr 'in front of', među:Instr 'between', pri:Gen 'by', blizu:Gen 'near', poslije:Gen 'after', osim:Gen 'except', umjesto:Gen 'instead' and radi:Gen 'for'.

Table 7. Ranking of Croatian prepositional phrases by frequency in L1 CS and CDS

\begin{tabular}{|l|l|l|l|}
\hline Preposition & English translation & CS & CDS \\
\hline u:Acc & in, to (directive) & 1 & 3 \\
\hline s(a):Instr & with & 2 & 1 \\
\hline u:Loc & in (locative) & 3 & 2 \\
\hline na:Acc & to, on & 4 & 5 \\
\hline za:Acc & for & 5 & 6 \\
\hline na:Loc & at, on(to) & 6 & 4 \\
\hline od:Gen & from, of & 7 & 7 \\
\hline kod:Gen & at, by & 8 & 8 \\
\hline iz:Gen & out of & 9 & 10 \\
\hline po:Loc & alongside & 10 & 9 \\
\hline
\end{tabular}


These data indicate that prepositional phrases in CS reflected the overall frequency of prepositional phrases in CDS, although not completely. In addition, several less common prepositional phrases in CDS did not appear in CS. The fact that some of these prepositional phrases nonetheless appeared regularly in CDS suggests that frequency alone cannot explain why they did not appear in CS.

\subsubsection{Bilingual data}

All four children demonstrated a similar pattern in their use of prepositional phrases: most frequent were $u: L o c$ 'at, in(to)' and $u: A c c$ 'in, to', followed by $s(a)$ :Instr 'with', za:Acc 'for' and kod:Gen 'at, by' (Table 8). In contrast, na 'on' appeared infrequently, which might be due to the relatively small data set of bilingual speech. Indeed, this may explain why only 11 prepositional phrases were observed in this group of children. Nevertheless, the percentage of tokens that were prepositional phrases was similar between the bilingual children (1-3\%) and monolingual children (2\%).

Table 8. Token frequencies of Croatian prepositional phrases in bilingual CS

\begin{tabular}{|c|c|c|c|c|c|c|c|}
\hline & Preposition & English translation & Ana & Lara & Marko & Filip & ALL \\
\hline 1 & u:Loc & in (locative) & 8 & 4 & 2 & 9 & 23 \\
\hline 2 & $\mathrm{u}: A c c$ & in, to (directive) & 1 & 4 & 7 & 3 & 15 \\
\hline 3 & s(a):Instr & with & 12 & 0 & 2 & 0 & 14 \\
\hline 4 & za:Acc & for & 4 & 8 & 0 & 1 & 13 \\
\hline 5 & kod:Gen & at, by & 7 & 5 & 0 & 0 & 12 \\
\hline 6 & na:Acc & to, on & 0 & 2 & 2 & 2 & 6 \\
\hline 7 & na:Loc & at, on(to) & 2 & 1 & 0 & 2 & 5 \\
\hline 8 & od:Gen & from, of & 3 & 1 & 0 & 0 & 4 \\
\hline 9 & bez:Gen & without & 2 & 0 & 0 & 0 & 2 \\
\hline 10 & ispod:Gen & under & 0 & 0 & 1 & 0 & 1 \\
\hline \multirow[t]{4}{*}{11} & uz:Acc & at, by, along & 0 & 0 & 1 & 0 & 1 \\
\hline & & All & 39 & 25 & 15 & 17 & 96 \\
\hline & & Tokens (All) & 1,317 & 1,019 & 723 & 1,373 & 4,432 \\
\hline & & $\begin{array}{l}\% \text { of tokens that were } \\
\text { prepositional phrases }\end{array}$ & $3 \%$ & $2.5 \%$ & $2 \%$ & $1 \%$ & $2 \%$ \\
\hline
\end{tabular}


In the CDS to which the bilingual children were exposed, 22 prepositional phrases appeared, all at a higher token frequency than in CS (Table 9). The most frequent prepositional phrases in CDS were u:Loc 'at, in(to)', $s(a)$ :Instr 'with', u:Acc 'in, to', na:Acc 'to, on' and na:Loc 'at, on(to)'. The percentage of tokens that were prepositions was 3.5\% in CDS, higher than that in bilingual CS (2\%) but similar to that in monolingual CDS (3\%).

Table 9. Token frequencies of Croatian prepositional phrases used in CDS with bilingual children

\begin{tabular}{|c|c|c|c|c|c|c|c|}
\hline & Preposition & English translation & Ana & Lara & Marko & Filip & ALL \\
\hline 1 & u:Loc & in (locative) & 35 & 19 & 18 & 25 & 97 \\
\hline 2 & s(a):Instr & with & 12 & 14 & 24 & 12 & 62 \\
\hline 3 & $\mathrm{u}: \mathrm{Acc}$ & in, to (directive) & 6 & 15 & 21 & 11 & 53 \\
\hline 4 & na:Acc & to, on & 9 & 7 & 10 & 10 & 36 \\
\hline 5 & na:Loc & at, on(to) & 10 & 8 & 7 & 8 & 33 \\
\hline 6 & za:Acc & for & 6 & 9 & 9 & 6 & 30 \\
\hline 7 & kod:Gen & at, by & 7 & 9 & 7 & 1 & 24 \\
\hline 8 & od:Gen & from, of & 4 & 3 & 2 & 2 & 11 \\
\hline 9 & iz:Gen & out of & 1 & 7 & 2 & 0 & 10 \\
\hline 10 & ispod:Gen & under & 0 & 1 & 3 & 0 & 4 \\
\hline 11 & iza:Gen & behind & 0 & 0 & 3 & 0 & 3 \\
\hline 12 & u:Gen & at & 0 & 0 & 2 & 1 & 3 \\
\hline 13 & s:Gen & from & 0 & 3 & 0 & 0 & 3 \\
\hline 14 & uz:Acc & at, by, along & 0 & 0 & 3 & 0 & 3 \\
\hline 15 & po:Loc & alongside & 1 & 0 & 0 & 1 & 2 \\
\hline 16 & prema:Loc & towards, according to & 0 & 2 & 0 & 0 & 2 \\
\hline 17 & po:Acc & for & 0 & 1 & 0 & 0 & 1 \\
\hline 18 & ispred:Gen & in front of & 0 & 1 & 0 & 0 & 1 \\
\hline 19 & bez:Gen & without & 1 & 0 & 0 & 0 & 1 \\
\hline 20 & između:Gen & between & 0 & 1 & 0 & 0 & 1 \\
\hline 21 & o:Loc & about & 0 & 0 & 0 & 1 & 1 \\
\hline \multirow[t]{4}{*}{22} & niz:Acc & down & 0 & 0 & 1 & 0 & 1 \\
\hline & & All & 92 & 100 & 112 & 78 & 382 \\
\hline & & Tokens (AII) & 2,042 & 2,476 & 3,516 & 2,848 & 10,882 \\
\hline & & $\begin{array}{l}\% \text { of tokens that were } \\
\text { prepositional phrases }\end{array}$ & $4.5 \%$ & $4 \%$ & $3 \%$ & $3 \%$ & $3.5 \%$ \\
\hline
\end{tabular}


The 10 most frequent prepositional phrases in CDS directed at bilingual children matched the 10 most frequent in those children's CS, although the specific ranking of each prepositional phrase by frequency varied slightly (Table 10). Thus, the input that parents provided to their children was reflected in the output.

Table 10. Ranking of Croatian prepositional phrases by frequency in 2L1 CS and CDS

\begin{tabular}{|l|l|l|l|}
\hline Preposition & English translation & CS & CDS \\
\hline u:Loc & in (locative) & 1 & 1 \\
\hline u:Acc & in, to (directive) & 2 & 3 \\
\hline s(a):Instr & with & 3 & 2 \\
\hline za:Acc & for & 4 & 6 \\
\hline kod:Gen & at & 5 & 7 \\
\hline na:Acc & to, on & 6 & 4 \\
\hline na:Loc & at, on(to) & 7 & 5 \\
\hline od:Gen & from, of & 8 & 8 \\
\hline bez:Gen & without & 9 & 9 \\
\hline ispod:Gen & under & 10 & 10 \\
\hline
\end{tabular}

\section{DISCUSSION AND CONCLUSION}

This study aimed to describe the order of acquisition of Croatian prepositional phrases in mono- and bilingual children, as well as developmental changes in the number and diversity of prepositional phrases that they use. We also assessed how much these results were influenced by the frequency of the same prepositional phrases in CDS.

The three monolingual children began to utter prepositional phrases around the same time: Marina at 1;9 years, Antonija at 1;7 years, and Vjeran at $1 ; 8$ years. The first preposition for all three children was $u$ 'in', which was used to express both location and direction. All prepositional phrases used by the monolingual children were also used by the bilingual children, who were older (age 3;0/3;1 and 3;3/3;4). Unfortunately, since the bilingual data were collected as part of an exploratory study, we were unable to determine when those children began to use prepositional phrases.

To explore how number and diversity of prepositional phrases might vary during early language acquisition, we evaluated preposition use by monolingual children at three ages: 1;7-2;0 years, 2;1-2;6 years and 2;7-3;0 years. The most frequent prepositional phrases in early CS were $u: L o c$ 'in' and $u: A c c$ 'in, to', followed by na:Loc 'at, on(to)' and na:Acc 'to, on. These 
prepositional phrases occurred most often at the age of 1;7-2;0 years, when they accounted for $76 \%$ of all prepositional phrases. Their frequency fell to $60 \%$ of all prepositional phrases at the age of $2 ; 1-2 ; 6$ years, and again to $51 \%$ of all prepositional phrases at the age of 2;7-3;0 years. Diversity of prepositional phrases increased with age, reflecting the continuous growth of prepositional richness during language development. The monolingual results for the third (oldest) age were similar to the results for bilingual children, where $53 \%$ of all prepositions were $u$ 'in' and $n a$ 'on' ( $u: L o c-29 \%$ and $u: A c c-12 \%$; na:Loc - 7\% and na:Acc - 5\%).

Our analysis supports the idea that parental input influences language acquisition (e.g. Gathercole \& Hoff 2007; Hoff \& Core 2013; Rowe 2012). The 10 most frequent prepositional phrases in monolingual or bilingual CS were also the 10 most frequent in the corresponding CDS. Although our bilingual dataset should be treated with caution because it was less extensive than the monolingual dataset, 10 of the 11 prepositional phrases used by bilinguals matched those used by monolinguals. Only $u z: A c c$ 'at, by, along' was used by bilinguals, but not by monolinguals.

Bilingual and monolingual children in our study demonstrated preferences for spatial prepositional phrases, possibly because of specific play situations (cf. Leseman et al. 2001). This is consistent with studies indicating that spatial prepositional phrases appear in CS before other types of prepositional phrases (e.g. Clark 2004, 1973; Dromi 1979; Johnston and Slobin 1979; Meints et al. 2002).

The bilingual children in our study used fewer prepositional phrases than the monolingual children. This and any other differences between the two groups should be interpreted with caution because the bilingual children were older and were recorded at only two time points three months apart. Therefore, the observed differences may simply be the result of differences in corpus size. A denser sample of bilingual data is necessary to obtain a more holistic picture of differences in prepositional use between monoand bilingual children.

While some argue that the same principles guide language acquisition by mono- and bilinguals (e.g., Slobin, 1973), another view holds that bilinguals acquire language differently (e.g. Volterra \& Taeschner, 1978). The findings of the present study are consistent with research supporting the former view (for an overview, see de Houwer, 2002). Nevertheless, our data prevent us from drawing any strong conclusions in this regard because of differences in corpus size, sampling, and age between the mono- and bilingual children. 
In accordance with research in other languages, the present study suggests that the frequency of Croatian prepositional phrases in CDS influences their acquisition by monolingual and bilingual children. Further study should verify and extend our findings by comparing corpora of similar size. In addition, such work should examine bilingual data prior to 3 years of age in order to obtain a more complete picture of prepositional use in early language development.

\section{Acknowledgements}

This work has been supported Croatian Science Foundation under the project Multilevel approach to spoken discourse in language development (UIP2017-05-6603).

\section{REFERENCES}

Ambridge, B., \& Lieven, E. V. M. (2011) Child language acquisition: Contrasting theoretical approaches.Cambridge; New York: Cambridge University Press.

Armon-Lotem, S. (2014) Between L2 and SLI: Inflections and prepositions in the Hebrew of bilingual children with TLD and monolingual children with SLI. Journal of Child Language, 41(01), 3-33.

Brown, R. (1973) A first language: The early stages. Oxford, England: Harvard U. Press. Oxford, England: Harvard University Press.

Cartmill, E. A., Armstrong, B. F., Gleitman, L. R., Goldin-Meadow, S., Medina, T. N., \& Trueswell, J. C. (2013) Quality of early parent input predicts child vocabulary 3 years later. Proceedings of the National Academy of Sciences, 110(28), 11278-11283.

Clark, E. V. (1973) Non-linguistic strategies and the acquisition of word meanings. Cognition, 2, 161-182.

Clark, E. V. (Ed.). (1986) The Acquisition of Romance, with special reference to French by Eve $V$. Clark. Vol. 7: The Acquisition of Romance, with special reference to French. Hillsdale, N.J.: Erlbaum.

Clark, E. V. (2004) How language acquisition builds on cognitive development. Trends in Cognitive Sciences, 8(10), 472-478.

Cristofaro, T. N., \& Tamis-LeMonda, C. S. (2012) Mother-child conversations at 36 months and at pre-kindergarten: Relations to children's school readiness. Journal of Early Childhood Literacy, 12(1), 68-97.

Čamber, M. (2020) Simultaneous acquistition of Austrian German and Croatian at home and in preschool (unpublished doctoral thesis). Vienna: University of Vienna.

De Houwer, A. (2002) Comparing monolingual and bilingual acquisition. Alkalmazott Nyelvtudomány [Hungarian Journal of Applied Linguistics], II: 5-19.

De Houwer, A. (2005) Early bilingual acquisition: Focus on morphosyntax and the separate development hypothesis. In J. F. Kroll \& A. M. B. De Groot (Eds.), Handbook of bilingualsim. Psycholinguistic approaches (pp. 30-48). Oxford: OUP. 
De Houwer, A. (2007) Parental language input patterns and childrens bilingual use. Applied Psycholinguistics, 28(3), 411-424.

Dromi, E. (1979) More on the acquisition of locative prepositions: An analysis of Hebrew data. Journal of Child Language, 6(3), 547-562.

Durkin, K. (1981) Aspects of late language acquisition: School children's use and comprehension of prepositions. First Language, 2(4), 47-59.

Ellis, N. C. (2002) Frequency effects in language processing. Studies in Second Language Acquisition, 24.(02).

Gathercole, V. C. M., \& Hoff, E. (2007) Input and the Acquistion of Language: T\#ee Questions. In E. Hoff \& M. Shatz (Eds.), Blackwell Handbook of Language Development. Malden, MA ; Oxford: Blackwell.

Gathercole, V. C. M., \& Thomas, E. M. (2005) Minority language survival: Input factors influencing the acquisition of Welsh. In J. Cohen, K. McAlister, K. Rolstad, \& J. MacSwan (Eds.), Proceedings of the 4th International Symposium on Bilingualism. Somerville, MA: Cascadilla Press.

Grießhaber, W. (2007) Zweitspracherwerbsprozesse als Grundlage der Zweitsprachförderung. In B. Ahrenholz (Ed.), Deutsch als Zweitsprache. Voraussetzungen und Konzepte für die Förderung von Kindern und Jugendlichen mit Migrationshintergrund (pp. 31-48). Freiburg i. Br.: Fillibach.

Grießhaber, W. (2012) Die Profilanalyse. In B. Ahrenholz (Ed.), Einblicke in die Zweitspracherwerbsforschung und ihre methodischen Verfahren.

Grosjean, F. (2010) Bilingual: Life and Reality.

Hoff, E., \& Core, C. (2013) Input and Language Development in Bilingually Developing Children. Seminars in Speech and Language, 34(04), 215-226.

Hržica, G. (2011) Glagolske kategorije aspekta, vremena i akcionalnosti u usvajanju hrvatskog jezika (Doktorska disertacija). Filozofski fakultet, Zagreb.

Hržica, G. (2012) Daj mi to napisaj: Preopćavanja glagolske osnove u usvajanju hrvatskog jezika. Suvremena lingvistika, 38(74), 189-208.

Hržica, G., Brdarić, B., Tadić, E., Goleš, A., \& Roch, M. (2015) Dominantnost jezika dvojezičnih govornika talijanskog i hrvatskog jezika. Logopedija, 5(2), 34-40.

Jeuk, S. (2003) Erste Schritte in der Zweitsprache Deutsch. Eine empirische Untersuchung zum Zweitspracherwerb türkischer Migrantenkinder in Kindertageseinrichtungen. Freiburg i. Br:: Fillibach.

Johnston, J. R., \& Slobin, D. I. (1979) The development of locative expressions in English, Italian, Serbo-Croatian and Turkish. Journal of Child Language, 6(03).

Kaštelančić, A. (2014) Usvajanje prijedloga u hrvatskom jeziku (Disertacija). Svučilište Zagreb, Zagreb.

Klinge, S. (1990) Prepositions in bilingual language acquisition. In J. Meisel (Ed.), Two first languages. Early grammatical development in bilingual children (pp. 123-156). Dordrecht, The Netherlands: Foris.

Korecky-Kröll, K., Uzunkaya-Sharma, K., Czinglar, C., \& Dressler, W.U. (2016) Der Input im Elternhaus und Kindergarten als wichtiger Faktor für den Spracherwerb von austrotürkischen Kindern, In: J. Carvill Schellenbacher, J. Dahlvik, H. Fassmann \& C. Reinprecht (Eds.), Migration Und Integration - Wissenschaftliche Perspektiven Aus Österreich (pp. 67-87). Jahrbuch 3/2016. V\&R unipress, Vienna University Press, Göttingen. 
Korecky-Kröll, K., \& Buchegger, L. (2018) Tagging spatial and temporal PPs with two-way prepositions in adult-child and adult-adult conversation in German in Austria. In A. U. Frank, C. Ivanovic, F. Mambrini, M. Passarotti, \& C. Sporleder (Eds.), Gerastree Proceedings, GTP 1 (pp. 113-122). 25-26 January 2018 Vienna, Austria: Department of Geoinformation, TU Wien.

Kovačević, M. (2002) Croatian Corpus, CHILDES. Retrieved February 4, 2015, from https:// childes.talkbank.org/access/Slavic/Croatian/Kovacevic.html.

Kovačević, M., \& Anđel, M. (1999) Early verbs in acquisition of Croatian. Conference presentation presented at the 27. Österreichische Linguistiktagung, Vienna.

Kovačević, M., Palmović, M., \& Hržica, G. (2009) The acquisition of case, number and gender in Croatian. In U. Stephany \& M. D. Voeikova (Eds.), Development of nominal inflection in first language acquisition: A cross-linguistic perspective (pp. 153-177). Berlin: Mouton de Gruyter.

Leikin, M. (1998) Acquisition of Locative Prepositions in Russian. Journal of Psycholinguistic Research, 27(1), 91-108.

Leseman, P. P. M., Rollenberg, L., \& Rispens, J. (2001) Playing and working in kindergarten: Cognitive co-construction in two educational situations. Early Childhood Research Quarterly, 16(3), 363-384.

MacWhinney, B. (2000). The CHILDES Projekt: Tools for Analyzing Talk. 3rd Edition. (3rd ed.). Mahwah: NJ: Lawrence Erlbaum Associates.

MacWhinney, Brian. (2005) A unified model of language acquisition. In J. F. Kroll \& A. M. B. De Groot (Eds.), Handbook of bilingualsim. Psycholinguistic approaches (pp. 49-67). Oxford: OUP.

Major, R.C. (2008) Transfer in second language phonology. In: J.G.H Edwards, \& M.L. Zampini (eds.), Phonology and second language acquisition (pp. 63-94). Philadelphia/ Amsterdam: John Benjamins..

Matovac, D. (2013) Semantika hrvatskih prijedloga (Doktorski rad). Sveučilište Josipa Jurja Strossmayera, Osijek.

Meints, K., Plunkett, K., Harris, P. L., \& Dimmock, D. (2002) What is 'on' and 'under' for 15-, 18- and 24- month-olds? Typicality effects in early comprehension of spatial prepositions. British Journal of Developmental Psychology, 20(1), 113-130.

Meisel, J. M. (2001) The simultaneous acquisition of two first languages. Early differentiation and subsequent development of grammars. In J. Cenoz \& F. Genesee (Eds.), Trends in bilingual acquisition (pp. 11-41). Amsterdam; Philadelphia: John Benjamins.

Moguš, M., Bratanić, M., \& Tadić, M. (1999) Hrvatski čestotni rječnik. Zagreb: Zavod za lingvistiku Filozofskog fakulteta : Školska knjiga.

Pearson, B. Z. (2008) Raising a bilingual child: A step-by-step guide for parents. London: Random House.

Pienemann, M. (1998) Language Processing and Second Language Development: Processability Theory. Amsterdam: Benjamins.

Place, S., Hoff, E. (2011) Properties of dual language exposure that influence two-year-olds' bilingual proficiency. Child Development, 82, 1834-1849.

Poljak, A., Hrzica, G., \& Arapovic, D. (2015) Morfolosko oznacavanje zivosti: Razlicito oznacavanje objekta u usvajanju hrvatskoga jezika. Suvremena Lingvistika, 41(79), 21-39. 
Reich, H. H. (2008) Die Sprachaneignung von Kindern in Situationen der Zwei- und Mehrsprachigkeit. In K. Ehlich, U. Bredel, \& H. H. Reich (Eds.), Referenzrahmen zur alterssprezifischen Sprachaneignung - Forschungsgrundlagen: Vol. Bd. 29/II (pp. 163-170). Retrieved from https://www.bmbf.de/pub/Bildungsforschung_Band_29_2.pdf

Rivière, J., Lécuyer, R., \& Hickmann, M. (2009) Early locomotion and the development of spatial language: Evidence from young children with motor impairments. European Journal of Developmental Psychology, 6(5), 548-566.

Rowe, M. L. (2012) A Longitudinal Investigation of the Role of Quantity and Quality of ChildDirected Speech in Vocabulary Development: Child-Directed Speech and Vocabulary. Child Development, 83(5), 1762-1774.

Savić, M., Anđelković, D. (2004) The acquisition of prepositions in Serbian: Factors and mechanisms of development. Psihologija, 37(4), 415-450.

Savić, M., Anđelković, D. (2011) The role of input frequency in early language production: Children's usage of Serbian prepositions. In I. Guzlow \& N. Gagarina (Eds.), Frequency effects in language acquisition (pp. 145-180). Berlin: Mouton de Gruyter.

Slobin, Dan I. (1973) Cognitive prerequisites for the development of grammar. In C. A. Ferguson \& D. I. Slobin (Eds.), Studies of child language development (pp. 175-208). New York: Holt, Rinehart, \& Winston.

Tomasello, M. (1987). Learning to use prepositions: A case study. Journal of Child Language, 14(01), 79.

Volterra, V. \& Taeschner, T. (1978). The acquisition and development of language by bilingual children. Journal of Child Language, 5, 311-326.

Weinreich, U. (1953) Languages in contact: Findings and problems. The Hague: Mouton.

Yip, V., \& Matthews, S. (2007) The Bilingual Child: Early Development and Language Contact. Cambridge: Cambridge University Press.

Županović Filipin, N. (2015) Usvajanje govora kod dvodijalektalnoga djeteta: jezični razvoj, utjecaji i ishodi. Jezikoslovlje, 16(2-3), 275-305. 


\title{
Usvajanje prijedložnih izraza u jednojezičnom i dvojezičnom razvoju
}

\author{
Gordana Hržica \\ gordana.hrzica@erf.unizg.hr \\ Department of Speech Therapy, Faculty of Education and Rehabilitation \\ Sciences, University of Zagreb
}

Marina Čamber

marina.camber@ph-noe.ac.at

University College of Teacher Education in Lower Austria

\author{
Ana Kaštelančić Igrc \\ ana.kastelancic@gmail.com \\ "Slava Raškaj" Educational Centre Split
}

\begin{abstract}
Ako ih usporedimo sa sadržajnim riječima, prijedlozi se pojavljuju kasnije tijekom usvajanja prvog jezika (Leikin, 1998). U ovom se radu želi opisati usvajanje prijedložnih izraza u hrvatskom jeziku, s posebnim naglaskom na čestotnost, uzevši u obzir jednojezični i dvojezični razvoj.

Istraživanje je provedeno na transkriptima spontane konverzacije djece i odraslih govornika. Troje jednojezične djece snimano je jednom mjesečno od dobi 1;5 do 3;0, a četvoro dvojezične djece u dvije vremenske točke (3;0 i 3;4). Sva su djeca snimana u spontanim situacijama kod kuće ili oko kuće, većinom u interakciji s majkama.

Rezultati upućuju da se čestotnost prijedloga u govoru usmjerenom djetetu odražava u dječjem jeziku. Također rezultati su u skladu s istraživanjima koja pokazuju da je jezični razvoj dvojezične i jednojezične djece sličan, pri čemu dvojezična djeca mogu pokazivati određen stupanj kašnjenja. No, za bilo kakve pouzdanije zaključke o jednojezičnom i dvojezičnom razvoju potrebna je veća količina podataka dvojezične djece.
\end{abstract}

Ključne riječi: dječji jezik, prijedlozi, čestotnost, govor usmjeren djetetu, jednojezični razvoj, dvojezični razvoj 